of day until 1953. Although Luther's view of the Holy Spirit dominates the whole of his theology it is not always easy to pinpoint his thought. This Dr. Prenter succeeds in doing to a marked degree. Attention is now being given to Luther's hermeneutics and before long we may look for major works on this theme. Raymond F. Surburg has dealt with the historical context in 'The Significance of Luther's Hermeneutics for the Protestant Reformation' (Concordia Theological Monthly, 1953) and more recently J. Theodore Mueller has written, perhaps rather too emphatically, on 'Luther's Doctrine of Inspiration' (Christianity Today, 1957). W. Schwarz's Principles and Problems of Biblical Translation deals with the conflict of the inspirational and philological principles in the work of sixteenth century translation as reflected in the work of Reuchlin, Erasmus and Luther. He rather too neatly inserts Luther into the purely inspirational category, forgetting that recent research suggests that the Biblical humanist in Luther cannot be dismissed. In the realm of Christian Sociology the most useful work to appear is George W. Forell's Faith Active in Love: An Investigation of the Principles Underlying Luther's Social Ethics (cf. my review in the Evangelical Quarterly, April, 1955).

Space forbids any detailed mention of Roman Catholic contributions to this field, which have been considerable and generally marked by a new sympathy and honesty. P. Yves Congar has submitted Luther's ecclesiology to a detailed critique in Vraie et fausse Réforme dans l'Eglise and P. Louis Bouyer examines the fundamentals of his theology in The Spirit and Forms of Protestantism. Those who wish to consult a much fuller bibliography than the limits of this list will permit should turn to John Dillenberger's survey in Church History, June, 1956.

Sunderland.

A. SKEVINGTON WOOD.

\title{
RELIGIOUS SYNCRETISM IN PTOLEMAIC TEXTS
}

During the winter 1954/55, the writer took part in the archaeological excavations of the Mission Belge de Fouilles at El Kâb in Upper Egypt. After the dig he stayed one month at Karnak (Luqsor) to copy the unpublished texts covering the exterior walls of the Temple of Opet (Ptolemaic/Roman period). These walls are covered with inscriptions dating from the time of Caesar Augustus. They give geographical names, some of which were not known before.

During the winter 1955/56, he returned to Karnak where he spent another three months copying all the inscriptions covering the inside walls of the temple, which date for the greater part from the time of Ptolemy VIII Euergetes II (145-116 B.C.). These are religious texts which promise to be interesting for the study of syncretism in the Egyptian religion of later times. Some scenes show the Theban triad of Amun, Mut and Khonsu, but the epithets which accompany these gods are undoubtedly those of Orisis, Isis and Horus. The god Amun is represented in his own self, i.e. as one of the elements of the Ogdoad (the primeval forces before Creation), as father of the Eight (Ir-ta), as his own grandfather (Kematef) and as his own son (Amenopet). The point seems to be to try to explain how the son is not the inferior of the father, a problem which faced Christian theologians many centuries later. Such a tendency is already to be found in some Coffin Texts, which date from about 2000 B.C. The problems involved cannot be explained in a few words and we must refer to the writer's article 'A propos du temple d'Opet à Karnak', in the review Le Flambeau, a copy of which is to be found in Tyndale House Library. Any suggestion that the early Christian Fathers had knowledge of texts such as the Coffin Texts, which have been published only a few years ago by Professor A. de Buck of Leiden, must, of course, be rejected.

\section{NOTES AND NEWS}

C. de WIT.

\section{Recent Lectures at Tyndale House.}

Four Tyndale Lectures were delivered at Tyndale House in the course of the summer study groups: Mr. K. A. Kitchen on The Joseph Narratives and their Egyptian background '; Mr. E. A. Judge on 'Social Obligation in the New Testament '; Professor Gwyn Walters on 'The Intercession of the Spirit '; and Professor G. C. B. Davies on 'Some Aspects of the life of Henry Ryder, the first Evangelical Bishop'. Dr. Davies's lecture was the first of the new series of Tyndale Historical Theology Lectures. Mr. Judge having been appointed to a lectureship in the University of Sydney during the past year, his lecture was read in his absence.

In addition to these, there have been two lectures this year under the auspices of the Friends of Tyndale House. The late Professor Arndt spoke on the ArndtGingrich Lexicon on the day of its publication: and on a recent visit the Rev. 